\title{
SpeCific IgE INDUCEd by KudoA SP. (MyXosporea: Multivalvulida) antigens IN BALB/C MICE
}

\author{
MARTÍNEZ DE VELASCO G.*, RODERO M.* \& CUÉLLAR C.*
}

\section{Summary:}

The majority of Kudoa species infect the somatic muscle of fish establishing cysts. As there is no effective method to detect infected fish without destroying them, these parasited fish reach the consumer. We have developed this work to determine whether this parasite contains antigenic compounds capable of provoking an immune response in laboratory animals, in order to consider the possible immunopathological effects in man by the ingestion of Kudoa infected fish. BALB/c mice were injected by the subcutaneous route with the following extracts suspended in aluminium hydroxide: Group 1 (black Kudoa sp. pseudocyst extract), group 2 (white Kudoa sp. pseudocyst extract). Specific IgE levels were measured by ELISA. IgE detected in both groups 1 and 2 showed the possible allergenic nature of some of the components of the parasitic extracts.

KEY WORDS : antigen, ELISA, IgE, Kudoa, Myxosporea, pseudocyst
Résumé : IGE SPÉCIFIQUES INDUITES PAR LES ANTIGÈNES DE KUDOA SP. (Myxosporea: Multivalvulida) CHEZ la souris BALB/C

La plupart des espèces de Kudoa infectent le muscle somatique des poissons en formant des kystes. Comme il n'existe pas de méthodes efficaces pour détecter les poissons infectés sans les abîmer, ces poissons parasités arrivent jusqu'au consommateur. Nous avons développé ce travail pour déterminer si ce parasite contient des composants antigéniques susceptibles de provoquer une réponse immunitaire sur des animaux de laboratoire, et pour considérer les possibles effets immunopathologiques chez l'homme de l'ingestion de poissons infectés par Kudoa. Nous avons injecté à des souris $B A L B / C$, par voie sous-cutanée, deux types d'extraits en suspension dans de /'hydroxyde d'aluminium: groupe 1 (extraits de pseudokystes noirs de Kudoa sp.), groupe 2 (extraits de pseudokystes blancs de Kudoa sp.). Nous avons mesuré les niveaux d'lgE spécifiques par ELISA. Les niveaux d'lgE détectés dans chacun des groupes ont démontré la possible nature allergénique de quelques uns des composants des extraits parasitaires

MOTS CLÉS : antigen, ELISA, IgE, Kudoa, Myxosporea, pseudokyste
T The majority of Kudoa species infect the somatic muscle of marine and estuarine fish establishing cysts, which contain many spores. As the parasite grows, it produces proteolytic enzymes (Patashnik et al., 1982; Tsuyuki et al., 1982) that break down the filaments of the muscle fibre (Stehr \& Whitaker, 1986). While the parasite is within a muscle fibre, it is undetected by the host's immunological system. It is during this stage when the parasite contains many developing and mature spores that the infected fibres have a white appearance. As the parasite grows, it breaks the sarcolemma and the host recognizes the presence of the parasite (Moran et al., 1999). Then, there is a rapid development of a fibroblast layer around the parasite (Morado \& Sparks, 1986; Stehr \& Whitaker, 1986) and the cyst, more properly, pseudocyst, quickly acquires a black appearance. However, the process of resorption is slower than that of the development of

\footnotetext{
* Department of Parasitology, Faculty of Pharmacy, Complutense University, Pl. Ramón y Cajal s/n., 28040 Madrid, Spain. Correspondence: Dra. Carmen Cuéllar.

Fax: 34913941815 - E-mail: cuellarh@farm.ucm.es
}

pseudocysts. Consequently, the net effect is an accumulation of black pseudocysts as the infection progresses (Kabata \& Whitaker, 1986).

Considering that there is not any effective method to detect parasitized fish without destroying them, it is not unusual that infected fish reach the consumer. Despite the black or white appearance of pseudocyst in fish meat, they are frequently unnoticed and the myoliquefaction process is not always intense, especially in the older hosts.

In Spain, the consumption of imported Chilean hake Merluccius gayi gayi (Guichenot, 1848) is higher than the consumption of hake proceeding from the Cantabric Sea, which has a better quality but also a higher price. Kudoa infected fish have been lately detected in this imported hake, which is consumed not only fresh but also frozen.

Consequently, we have developed this work to determine whether this parasite contains antigenic compounds capable of provoking an immune response in laboratory animals, in order to consider the possible immunopathological effects by the ingestion of Kudoa infected fish. 


\section{MATERIALS AND METHODS}

\section{KUDOA SP. PSEUDOCYSTS}

K udoa sp. pseudocysts were manually obtained from the skeletal musculature of Chilean hakes Pseudocysts were carefully separated from any interfering fish tissue. Afterwards, they were classified as white pseudocysts and black pseudocysts by observing their content by light microscope and then finally frozen at $-20^{\circ} \mathrm{C}$ until used. Pseudocysts with intermediate characteristics were discarded.

\section{EXTRACTS}

Both Kudoa sp. pseudocyst forms and non-infected hake meat were individually homogenized in a handoperated glass tissue grinder in PBS at $4^{\circ} \mathrm{C}$. In order to release spore contents, Kudoa sp. homogenates were frozen at $-80^{\circ} \mathrm{C}$ and lately sonicated by 20 pulses of $10 \mathrm{~s}$ with a Virsonic 5 (Virtis, NY, USA) set at $70 \%$ output power, in an ice-water bath. All the homogenates were extracted in PBS at $4^{\circ} \mathrm{C}$ overnight. The hake meat homogenate was subsequently delipidized with $\mathrm{n}$-hexane and centrifuged as the Kudoa sp. homogenates at 8,497 $\mathrm{g}$ for $30 \mathrm{~min}$ at $4^{\circ} \mathrm{C}$ (Biofuge 17RS: Heraeus Sephatech, GmbH, Osterode, Germany). The supernatants were dialysed overnight at $4^{\circ} \mathrm{C}$ in PBS. Protein content of the extracts was estimated by the Bradford method (1976) and the extracts were frozen at $-20^{\circ} \mathrm{C}$ until used.

\section{ANIMALS AND IMMUNIZATION PROTOCOL}

Eighteen BALB/C mice were divided in three equal groups and injected by the subcutaneous route with the obtained extracts suspended in aluminium hydroxide (Imject ${ }^{\circledR}$ Alum, Pierce) as adjuvant: group 1 (immunization with $100 \mu \mathrm{g} /$ mouse of black Kudoa sp. pseudocyst extract), group 2 (immunization with $100 \mu \mathrm{g}$ /mouse of white Kudoa sp. pseudocyst extract), group 3 (immunization with $100 \mu \mathrm{g}$ /mouse of noninfected hake meat extract). Two weeks later, they were injected again with an equal dose. Besides, a noninjected identical group was used as a control group. The ratio $(\mathrm{v} / \mathrm{v})$ of adjuvant to extract was 1:3.

\section{SERA}

Animals were bled weekly, including the control group, under ether anaesthesia, by the retroorbital plexus, from the fourth to the $21^{\text {st }}$ week since the first immunization. Blood samples from each group of mice were pooled and centrifuged to obtain sera.

\section{SPECIFIC ANTIBODY LEVELS}

Specific antibody levels were measured by ELISA. The 96-well microtitre plates (Nunc-Immuno Plate Poly- sorp ${ }^{\mathrm{TM}}$, Brand Products, Denmark) were coated overnight at $4^{\circ} \mathrm{C}$ by the addition of $10 \mu \mathrm{g} / \mathrm{ml}$ per well of Kudoa sp. antigens diluted in a carbonated buffer to $0.1 \mathrm{M}$ at $\mathrm{pH} 9.6$ at $4^{\circ} \mathrm{C}$. Several wells were kept uncoated as a control for non-specific reactions. After washing the plates three times with $0.05 \%$ PBS-Tween 20 (PBSTween), blocking was carried out by adding $200 \mu \mathrm{l}$ per well of $0.1 \%$ BSA (Sigma, St-Louis, MO, USA) in PBS, incubating for one hour at $37^{\circ} \mathrm{C}$. After washing, $100 \mu \mathrm{l}$ of serum samples were diluted $1 / 10$ in PBS-Tween, $0.1 \%$ BSA, added in triplicate, against their homologous antigen, and incubated at $37^{\circ} \mathrm{C}$ for two hours. As negative controls, sera from the control group were used. Once the plates were washed, $100 \mu \mathrm{l}$ per well of a goat affinity-isolated, horseradish peroxidase-conjugated antibody specific to mouse IgE ( $\varepsilon$ ) (sheep, The Binding Site), at the appropriate dilution in PBS-Tween, $0.1 \%$ $\mathrm{BSA}$, were added and incubated for one hour at $37^{\circ} \mathrm{C}$. After washing, $100 \mu \mathrm{l}$ per well of substrate (O-phenylene-diamine; Sigma, St-Louis, MO, USA) were added at $0.04 \%$ in a phosphate-citrate buffer $(\mathrm{pH} 5.0)$ with $0.04 \%$ hydrogen peroxide. The reaction was stopped with $3 \mathrm{~N}$ sulphuric acid and the plates were read at $490 \eta \mathrm{m}$. Results were expressed as O.D.p/O.D. ${ }_{c}$ indexes by dividing the mean O.D. of the control from the mean O.D. of the test sera once the non-specific reaction with the BSA used in the blocking was subtracted.

\section{RESULTS}

The IgE production against their homologous antigens (Fig. 1) was higher in the mice injected with the black Kudoa sp. pseudocyst extract (Group 1) than that obtained with the white pseudocyst extract (Group 2), being the differences between both groups statistically significant in all the weeks $(\mathrm{p}<0.05)$;

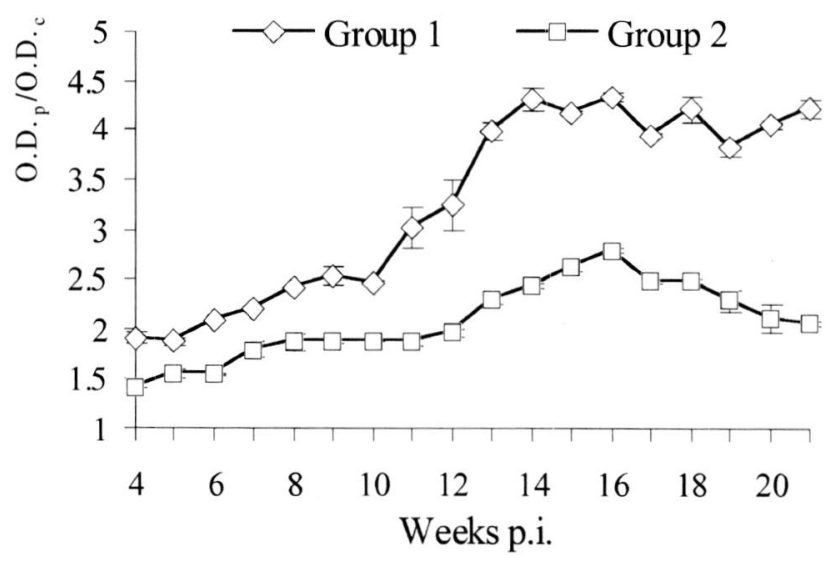

Fig. 1. - Dynamics of specific IgE production induced by the Kudoa sp. extracts in BALB/c mice against its homologous antigen. Group 1: immunization with $100 \mu \mathrm{g} /$ mouse of black Kudoa sp. pseudocyst extract. Group 2: immunization with $100 \mu \mathrm{g}$ /mouse of white Kudoa sp. pseudocyst extract. Standard errors are included. 
moreover, while in the later the IgE levels decreased after reaching a maximum, in the former they kept more or less constant until the end of the experiment. No IgE response was detected in the group immunised with the non-infected hake meat extract (Group 3).

\section{DISCUSSION}

I t seems that, despite the low or null response that myxosporeans provoke in their natural hosts (HalLlyday, 1974; McArthur, 1977; Siau, 1980), perhaps as a consequence of an antigenic mimicry (Pauley, 1974; McArthur \& Sengupta, 1982), these parasites can induce an antibody response in other animals (Muñoz et al., 2000; Chase et al., 2001). As a result of the extent of Myxosporea in the sea world, the ingestion of these parasites with the fish we usually eat is nowadays common, while their immune consequences are still unknown. Consequently, IgE detected in both groups 1 and 2 (immunized with black or white Kudoa sp. pseudocyst extract, respectively) showed the possible allergenic nature of some of the components of the parasitic extracts. These components could be responsible for type I hypersensitivity reactions after their ingestion. The absence of IgE response in the group inoculated with the non-infected hake meat (Group 3) proved that the results obtained in the Kudoa sp. groups (Groups 1 and 2), were a consequence of the parasitic extract injection and, in case of a possible contamination, it did not affect the results. The IgE production was higher in the mice injected with the black Kudoa sp. pseudocyst extract than that obtained with the white pseudocyst extract. It suggested that the extract obtained from black Kudoa sp. pseudocysts, which are featured with a higher density of degenerated mature spores (Stehr \& Whitaker, 1986), has a stronger ability to induce antibody responses. These pseudocysts were the most frequently found in the Chilean hakes.

\section{ACKNOWLEDGEMENTS}

This work was supported by research grant PR238/009444 (Danone SA).

\section{REFERENCES}

BRADFORD M. A rapid and sensitive method for the quantification of microgram quantities of protein utilizing the principle of protein-dye-binding. Analytical Biochemistry, 1976, 72, 248.

Chase J.C., Dawson-Coates J.A., Haddow J.D., Stewart M.H., Haines L.R., Whitaker D.J., Kent M.L., Olafson R.W. \& PEARSON T.W. Analysis of Kudoa thyrsites (Myxozoa: Myxo- sporea) spore antigens using monoclonal antibodies. Diseases of Aquatic Organism, 2001, 45, 121-129.

Hallyday M.M. Studies on Myxosoma cerebralis, a parasite of salmonids. IV. A preliminary immuno-fluorescent investigation of the spores of Myxosoma cerebralis. Nordisk Veterinaer Medicine, 1974, 25, 173-179.

Kabata Z. \& Whitaker D.J. Distribution of two species of Kudoa (Myxozoa: Multivalvulida) in the offshore population of the Pacific hake Merluccius productus (Ayres, 1855). Canadian Journal of Zoology, 1986, 64, 2103-2110.

MCARTHUR C.P. Immunopathological aspects of the hostparasite relationship in New Zealand freshwater eels. Ph. D. Thesis, University of Otego, Dunedin, NZ, March. 1977.

McArthur C.P. \& Sengupta S. Antigenic mimicry of eel tissues by a myxosporidean parasite. Zeitschrift für Parasitenkunde,1982, 66, 249-255.

Morado F. \& Sparks A.K. Observations on the host-parasite relations of the pacific whiting, Merluccius productus (Ayres), and its two myxosporidean parasites, Kudoa thyrsites (Gilchrist, 1924) and K. paniformis (Kabata \& Whitaker, 1981). Journal of Fish Diseases, 1986, 9, 445-455.

Moran J.D., Margolis L., Webster J.M. \& Kent M.L. Development of Kudoa thyrsites (Myxozoa: Myxosporea) in netpen-reared Atlantic salmon determined by light microscopy and a polymerase chain reaction test. Diseases of Aquatic Organisms, 1999, 37, 185-193.

Muñoz P., Sitjà-Bobadilla A. \& Álvarez Pellitero P. Antigenic characterization of Sphaerospora dicentrarchi (Myxosporea: Bivalvulida), a parasite from European sea bass Dicentrarchus labrax (Teleostei: Serranidae). Diseases of Aquatic Organism, 2000, 40, 117-124.

Patashnik M., Groninger H.S. Jr., Barnett H., Kudo G. \& Koury B. Pacific Whiting, Merluccius productus. Abnormal muscle texture caused by myxosporidian-induced proteolysis. Marine Fisheries Review, 1982, 44, 1-12.

PAUleY G. Fish sporozoa: extraction of antigens from Myxozoma cerebralis which mimic tissue antigens of rainbow trout (Salmo gairdneri, Rafinesque). Journal of the Fisheries Research Board of Canada, 1974, 31, 1481-1484.

STEHR C. \& WhitAKer D.J. Host-parasite interaction of the myxosporean Kudoa paniformis (Kabata \& Whitaker, 1981) and Kudoa thyrsites (Gilchrist, 1924) in the muscle of the Pacific whiting, Merluccius productus (Ayres): an ultrastructural study. Journal of Fish Diseases, 1986, 9, 505-517.

SIAU Y. Observations immunologique sur des poissons du genre Mugil parasités par la Myxosporidae Myxobolus exiguus Thélohan, 1895. Zeitschrift für Parasitenkunde, 1980, 62, 1-6.

Tsuyuki H., Williscroft S.N., Kabata Z. \& Whitaker D.J. The relationship between acid and neutral protease activities and the incidence of soft cooked texture in the muscle tissue of Pacific hake (Merluccius productus) infected with Kudoa paniformis and/or $K$. thyrsitis, held for varying times under different pre-fresh chilled storage conditions. Canadian Fisheries and Aquatic Sciences Technical Report, 1982, 1130, 39.

Reçu le 20 octobre 2002 Accepté le 2 juillet 2003 